\title{
The Universality of the Right to Education - A New Perspective
}

\author{
Elena Roxana Vişan \\ National School of Political Studies and Public Administration, (SNSPA/NUSPA), Bucharest, Romania \\ Member of the European Law Institute,Vienna, roxanne_lex@yahoo.com
}

\begin{abstract}
Against the backdrop of global change, and with a view to ensuring equal rights and freedoms for all, the need for deeper treatment of the universal nature of the right to education has emerged, while systematically preparing for quality education. The context of postmodern social development, global education policy outlines new priorities on equal opportunities, curriculum design, training organization, with a view to grounding a universal approach to all actors in the education process.
\end{abstract}

KEYWORDS: globalization, the legal nature, the right to education, the universal dimension

\section{Introduction}

Unprecedented changes in the world have led to an evolution on the international and European arena of human communities, through democratic reasons for the awareness of the right to education, an active and decisive asset in the valorizing the human being, in the development of a global diversity, to prefigure a society of common good.

The right to education and training is absolutely necessary in a democratic society and it must be a concern of all citizens by acquiring obligations to the own person, to the society in which we live, without any trace of "intolerance, without discrimination and negative competition" (The Human Rights Review 2015, 48).

Treated as an inherent side of the development of the human being, without Borders, a value of democratic society passed down from generation to generation, the right to education is the right, "without which mankind cannot acquire the valences of its ascension" (Vișan 2016, 30), a premise without which the other human rights cannot be exercised. I consider that, "no right granted to an individual who does not enjoy the apanage of education cannot, in itself, be accomplished, in the absence of a minimum degree of knowledge acquired" (Efrim 2014, 9), and also by its indivisibility, The right to education is considered "to be a tool for all human rights" (Meyer-Bisch 1998, para. 4).

Instrument and means of achieving and promoting fundamental human rights and freedoms, the right to education is focused on documents with national, regional and international legal value in the form of a right-freedom, guiding us the universal nature of all rights and the implication of education.

The universal vision of human rights is supported both by art. (1), All human beings are born free and equal in dignity and in rights" and art. (2) The Universal Declaration of Human Rights: "Every man may prevail over all rights and freedoms proclaimed (...) without distinction whatsoever (...)", recognizing, permanent concern in defending and harnessing man, raising him in The light of all state and non-State actors. In this respect we can see that human value is born by virtue of freedom and equality acquired only through education, because, "an educated individual is a truly free individual" (Moroianu Zlătescu, Moţ, Bulgaru 2016, 10) in the mind and in the senses. Behold, the right to education is the quintessential application of all other rights and freedoms, exercised through a complex process of becoming a human being, where education is the threshold between the sphere of natural man and the ancestral product of divine creation, through Selfknowledge and nutrition, "the need to be and become what the man has already been and is eager for perfection" (Şoitu 2016, 11).

The postmodernist period provides a new approach in terms of the universal nature of the right to education, "depending on the values considered priority for the construction of the 
education system" (Cristea 2016, 62), where the universal educational objective identifies with fair education, promoting lifelong learning opportunities-lifelong learning.

The universal nature of the right to education has been analyzed by verifying compliance with the following conditions: universal validity and universal acceptance of that right, on the one hand, and the formal universality and material universality of the right to education, of the other part (Coomans 1992, 258-268). These conditions are found in a complex framework for the exercise of the right to education, globally by the fact that its role is stated as an inextricably element of the orientation and formation of the young generation, in the setting up of a strong society and the national, European and international decision-making process.

Capable of influencing human values and legal norms, education must be seen as an integral part of the global social system comprising functions such as: Social solidarity, social control, social evolution and competitiveness in the labor market. Centrally positioned, the education system favors social actions, which interactively and diversify relations between man and society (Jinga 1993, 13), thus ensuring the universality of the right to education.

\section{Universal education policy}

We believe that the right to education is the way to the ascension of knowledge and good understanding between peoples, a universal right, belonging to any citizen, a right involving joint common programs, permanent and adaptable to present and future transformations. Therefore, the right to education by affirming universal cram draws social stability and economic prosperity, with a view to establishing a global identity, supported by the common sense of universal affiliation, existing between citizens.

In order to substantiate a common space to support the construction of a future in education, we need the free awareness and perception of all fundamental human rights and freedoms, the elimination of social inequalities, the professional potential of all citizens. A main landmark of the exercise of the right to education in the national, European and international context is the application of broad-spectrum educational public policies in the implementation of an overall educational strategy for the training of Employment of young people in relation to labor market requirements.

In international practice there are two main strands in ensuring the universal policy of education: goal-oriented policy aimed at global strategic issues and problem-oriented policy focusing on specific issues which must be resolved and which are related to a specific policy area" (Cojocaru 2015, 6).

Purpose-oriented policy aim at exercising the right to education in all its forms (formal, nonformal, informal) and at all levels of education, characterized by a number of major elements, of crucial significance for the education process: availability, accessibility, acceptability and adaptability (UN General Assembly 1996, E/CN.4/1999/49, para. 50). The four elements are known as Scheme 4-A (UN General Assembly 1996) a universal, essentially interdisciplinary directive, as follows (Vătăman 2018):

- Availability relates to the provision of institutions and formal education program in sufficient quantities, in the jurisdiction of States parts of the universal educational policy.

- Accessibility ensures all individuals, participation in the education process through a nondiscriminatory approach, a safe physical manner, or by participating in a convenient geographic location or through modern technology.

- Acceptability is the creation of an educational content, adapted to the psycho-pedagogical and age peculiarities of educators, with relevance to quality and efficiency.

- Adaptability gives education flexibility to respond to the needs of changing societies and communities within their various social and cultural settings.

Problem-oriented policy focus three key elements, which help to identify the main features of universal public policy (Lasswell 1951, 15):

- Interdisciplinary role in the application of methods and C In different areas, such as the study of political institutions, economic sciences, theory of organizations, law, sociology, psychology. 
- The orientation towards solving problems is moving towards real world problems, seeking solutions for them.

- Normativity explicitly assumes that it cannot be absolutely objective (Bulai, 2004), where it is considered that policy science is aimed at "improving knowledge, necessary to improve the practice of democracy" (Miroiu 2001, 23).

According to these directions, a number of substantial changes are made at the level of priorities regarding the universal education policy with emphasis on: curriculum design, new forms of education organization, training based on new technologies (Coombs 1989, 8-29).

This kind of universal policy of education is supported both on a theoretical and ideological level by the construction of a global and European dimension of education (Cristea 2016, 70).

Today, the global dimension of education is aimed at forming a society that will be able to meet the anticipated needs of the future, guiding the commitment of political actors to concrete actions, which determines: the formation and outsourcing of respect, awareness and valorization of human dignity, interest in pressing problems, promoting and deepening the values of the contemporary democratic society: freedom, social justice, peace culture, equality, solidarity, responsibility, and last but not least, creating the conditions for establishing a sustainable and safe world (Vişan 2018b, 325).

At the same time, globalization of education is also highlighted by the ability of the social system to adapt to changes in economic plan-managerial leadership model, based on the valorization of existing resources, in political plan-the model of social, strategic democracy, of capitalizing on human resources and equalization of chances of success, in cultural plan-the model of computerization of social products, of the conduct of each human personality (Cristea 2016, 70). All these actions carried out in various plans and concretized in the objectives of global projects refer to strategies for establishing sustainable development, as a relevant commitment guaranteeing continuity and the permanence of education (Vişan 2018b, 326).

The permanent and unaltered nature of education provides the human being with unrestricted access to continuity in development and affirmability. The idea of continuity of education offers a new perspective to treat it as a right for the individual and accountability for the decision makers (Şoitu 2016, 11). The concept of accountability entails the unequivocal involvement of the decision makers of European and international education policies, highlighted by the adoption of global projects, of which we mention: Millennium Declaration 2000, the U.N. decade On education for Sustainable Development (2005-2014), the World Program on Human Rights Education (2005-2019), Agenda 2030 for Sustainable Development and Education Program 2030 (Vişan 2018b, 326).

The content of the international instruments/programs mentioned above, establishes the global dimension of education, supported by five pillars, similar to the key competences of the Learning Act: Learn to know, learn to learn, Learn to do, learn to exist, learn to live with others (Amariei, Buker, Castanheira, Cugler and Cugler 2016). Each of these competences highlights the plurivalent and transdisciplinary character, necessary for a changing world, where knowledge, skill, competence, cooperation and affirmability are the pillars of resistance of global education (Delors 2013), continuously adapted to new global civilizations (Cristea 2016, 67).

Focusing on the European dimension of education, we find an incentive for lifelong learning, which enhances employability, mobility and social integration in the labor market. In this respect, a link is created between formal, non-formal and informal learning by supporting flexible educational pathways, opening up to different areas of education. Therefore, a quality promotion of learning and professional orientation among adults requires the introduction of new forms of active learning using new technologies, thus ensuring transparency and innovation in deepening learning.

A particular emphasis in stimulating this type of learning is the mobility of learners, teachers and trainers that should be gradually expanded, so that learning periods in other countries - both in Europe and in the world - become the rule, and not just the exception (O.J. of E.U. 2009/C 119/02). Thus, there is a fair and equitable professional integration, possible by acquiring the key competences of all the beneficiaries of the education act. Their acquisition claims that the political 
factors create a favorable climate, the exercise and assimilation of European policies directed mainly towards national ones, with greater emphasis on basic competences: literacy and increasing the attractiveness of science and technology, strengthening language skills.

Romania, as a Member State of the European Union, adopted on the recommendation of the European Parliament and the Council of the European Union the directives concerning the key competences of lifelong learning - "key competences for lifelong learning" (EUR-Lex 2006/962/EC, pp. 10-18), which outlines for graduates of lower and higher secondary education, a European training profile oriented on the formation of the eight key competences: communication in the mother tongue, communication in foreign languages, mathematical and basic skills in Sciences and technologies, digital skills, social and civic competences, entrepreneurial competences, spirit of initiative and cultural expression (Vişan 2014, 82), acquired through the reformation of the school curriculum.

The application of the European directives for the acquisition and deepening of the eight key competences of the young in pre-university education ensures a broad and useful perspective, a support of unit formation for the future development of some competences Specific professional objectives according to the academic environment concerned (Vişan 2018c, 342).

The quality of the education act as well as the acquisition of generic competences education levels is determined by the initial and continuous training of the teaching staff, but also by the administration and management of educational institutions through an effective quality assurance system. Initial and continuous training is a complex process that leads to professional development, centered on professional skills of methodological type, based on the reflective practice of the profession, the broadening of scientific and practical training, by Analogies of related domains, with specialized interference, ideological pluralism, multiculturalism, polycentrism, associated with teamwork, resulting in the formation of situational and orientation analysis competences in sociocultural environments as diverse as possible (Vişan 2018c, 209).

The Europeanisation of the educational framework is also highlighted by ,the formation of European citizens, endowed with European information and competences, in the spiritual values of Europe, which have a culture, conscience and European identity" (Potolea, Neacşu et al 2008, 14). Therefore, the size of European education aims to promote equity, social cohesion and active citizenship, which allows all citizens, irrespective of socio-economic circumstances, to acquire, update and develop throughout the lifetime of both job-specific skills and key competences necessary to enable employment and continuation of learning, active citizenship and intercultural dialogue (O.J. of E.U., 2009, C 119/4).

The relevant tendency to achieve this objective relates to a common framework for cooperation in order to ensure early education, the inclusion of people from disadvantaged backgrounds, those with special needs, as well as migrants. Early education is based on the substantiation and development of the concept of education for children under three years, a necessity stemming from the priorities of education at European and national level, pillar for lifelong learning, which is long-term asserted decreasing the rate of school dropout, improving the child's school success rate.

The meaning of the term inclusion is addressed from the perspective of several forms: improving education conditions at the level of special education, preventing school abandonment and improving the rate of school success for children with special needs (CSN), as well as the right of participation of the different categories of migrants at initiation courses in the mother tongue, in accordance with the legislative amendments in force. The two processes, education and inclusion favor the appropriation and transmission of democratic values, multi-cultural competences, as priorities necessary for the fight against all forms of discrimination (Mihalache, Baicu, Marin, 2015).

Ensuring a global and European dimension of education through the connection between theoretical and ideological aspects, strengthens the universal framework of the right to education, with permanent, decisive vibrations, indispensable to ,a understanding holistic and systemic 
education at the border between millennia" (Văideanu, 1988), where the universality of education identifies with the ,spirit of responsible global citizenship” (UNESCO 2013).

\section{Conclusions}

The accessibility and transparency of the implementation of the right to education at European and international level generates positive perspectives in the formation of young people, future citizens, leading to the maintenance of a global community based on culture as Human rights and peacekeeping in the world. The application and promotion of universal legal instruments, which stimulate all state and non-State actors in order to implement universal educational policies, will determine the formation of citizens today and tomorrow-social partners and Economic growth, pillars in the advancement of mankind.

The proposed theme gives us elements of cohesion and awareness of the role that the right to education holds, with profound meaning to lifelong learning - "learning throughout life", where the European education policy makers and international, together with national authorities are looking for solutions to guarantee the achievement of the stated goals: One hour a day - one week a year! (Şoitu 2016,9). The slogan is imperative and is addressed to the decision makers of each education system, recalling that the formation and development of the human resource requires a constant process of feeding and reforming the right to education, as a universal right of all actors involved (Vişan 2018a, 212).

Supported by the effective and effective exercise of the right to education, the training process for educators must be regarded as a worldwide, universal imperative, addressed to all State bodies to ensure compliance with global policies, with a view to Facilitating education as a means of national, regional and international development.

\section{References}

Amariei, M., Buker G, Castanheira A., Cugler M, Cugler N. 2016. Global How? Facilitating Global Education. Trainer's Manual. Baden-Wurttemberg, Germany: European Union, Cameos-Instituto da Cooperacao e da Lingua - Portugalia. [Online] Available at: http:// www.global-how.de. December 2018.

Bulai, A. 2004. The ideological foundation of public policy. Public Policy- course. Bucharest.

Cojocaru, T. 2015. "Educational Policy: Concept and Trends". In Ex Cathedra Review, no 1. Chişinău: Didactica Pro. [Online], Available at: https://ibn.idsi.md/sites/default/files/imag_file/5_8_Politici\%20educationale_concept $\% 20$ si\%20tendinte.

Coomans, F. 1992. The International Protection of the Right to Education, Ph.D Thesis, Maastricht University.

Coombs, P.H. 1989. La crise mondiale de l'education, trad. de Boeck Universite. Bruxelles.

Cristea, S. 2016. Education.Concept and analysis. Bucharest: Didactica.

Delors, J. 2013. The treasure within: Learning to know, learning to do, learning to live together and learning to be. Int. Rev. Educ. 59:319-330. Available at: http://www.osci-mena.org/upload/1/wysiwyg/Delors_article_review_of Education_2013, March 10.

Efrim, A. D. The Right to Education. Ph.D Thesis. 2014: University of Craiova, February 27. [Online] Available at: http://mecanica.ucv.ro/ScoalaDoctorala/Temp/Rezumate/EFRIM\%20DRAGOS\%20ALEXANDRU\%20$\% 20$ rezrom.pdf.

EUR-Lex. 2006. Recommendation of the European Parliament and of the Council of 18 December 2006 on key competences for lifelong learning. 2006/962/EC. Available at: http://data.europa.eu/eli/reco/2006/962/oj.

Jinga, I. 1993. Education Leadership. Bucharest: Didactica and Pedagogica Publishing House.

Lasswell, H.D. 1951. "The Policy Orientation.” Communication Researchers and Policy-Making, 1951.

Meyer-Bisch, P. 1998. The right to education in the context of cultural rights. U.N. E/C.12/1998/17, para. 4.

Mihalache, I., Baicu M., Cosmin M. 2015. Educational Management. [Online] Available at: http://www.pascatreangajare.ro/wp-content/uploads/2015/04/Management-educational-Suport-de-curs.pdf.

Miroiu, A. 2001. Introduction to public policy analysis. Bucharest: Paideia Publishing House.

Moroianu, Zlătescu I., Moţ A., Bulgaru A. 2016. "Education. The right to education and human rights education.” In Human Rights Review. Bucharest: IRDO.

Official Journal of European Union. 2009/C 119/02. Council conclusions of 12 May 2009 on a strategic framework for European cooperation in education and training - "ET 2020".

Official Journal of European Union. 2009. C 119/4.

Potolea, Neacşu, Iucu, Pânişoară. 2008. Psycho-pedagogical training. Manual for Completion and Didactic Degree II. Iaşi: Polirom Publishing House. 
Tomasevski, Katarina. Preliminary report of the Special Rapporteur on the right to education, submitted in accordance with Commission on Human Rights resolution 1998/33 E/CN.4/1999/49, para.50. [Online] Available at: http://repository.un.org/handle/11176/223172, accessed on February 18, 2018.

The Human Rights Review, no 4/2015. Bucharest: IRDO.

Şoitu, L. 2016. "Lifelong learning education, everyone's right and everyone's responsibility". In Human Rights Review, no 1. Bucharest: IRDO.

UNESCO. 2013. Global Citizenship Education. An emerging perspective. Outcome document of the Tehnical Consultation on Global Citizenship Education. Paris, [Online] Available at: http://www.unesdoc.unesco.org/images/0022/002241/224115E.pdf.

UN General Assembly. (1996). "International Covenant on Economic, Social and Cultural Rights”, Treaty Series 999 (1966): 171, adopted and opened for signature, ratification and accession by General Assembly resolution 2200A (XXI) of 16 December 1966. Available at: http://www.ohchr.org/EN/ProfessionalInterest/Pages/CESCR.aspx, accessed on February 2018.

Văideanu, G. 1988. Millennium Border Education. Bucharest: Politică Publishing House.

Vătăman, D. 2018. Legal Protection of the Right to Education in Romania and European Union. Challenges of the Knowledge Society: 705-711. Available at: https://search.proquest.com/docview/2130763001?accountid=15533.

Vişan, E.R. 2014. "The need to study human rights and fundamental freedoms from the point of view of European education." In Human rights - an issue that is always present, edited by Codiţă D., E.R. Vişan. Ploieşti: Karta Graphic.

Vişan, E.R. 2018a. "Efficiency of human resources in the education system through professional development." In Educational management in class and in school, edited by Mihail Rus C., Cârstea M.L. Sofronia A.C., Sofronia P.P. Iaşi: Lumen Publishing House.

Vişan, E.R. 2018b. Theoretical Foundations on the Global Dimension of Education In History - Memory - Renaissance, edited by F. Ciobotaru, L. Iordăchescu, G. Săndulescu. Iaşi: StudiS

Vişan, E.R. 2018c. "The relationship of the national education system with the labor market." In Public Responsibility in Education, edited by Constantinescu G., Zîrnă C. Constanţa: Crizon.

Vişan, E.R.. 2016. "Education for values through human rights and fundamental freedoms." In Human Rights Review, no 4. Bucureşti: IRDO. 